Acta Hispanica (2020) Supplementum II: 141-150

\title{
INTERREGIONALISM: THE CASE OF LATIN AMERICA
}

\author{
BERNADETT LEHOCZKI
}

Corvinus University of Budapest

\begin{abstract}
The aim of this study is to give an introduction to the place and role of Latin America as a world region in interregional relations. Latin America -at the regional and the state level- has long and deep experiences in being involved in inter-regional cooperation, a new element of global governance. After a short introduction to the phenomenon of interregionalism, the study focuses on the Latin American way of involvement and participation in inter-regional cooperation trying to detect special regional characteristics for deeper understanding.

Keywords: Latin America, Interregionalism, Inter-Regional Cooperation, Foreign Policy of Latin America.
\end{abstract}

\section{Interregionalism - definition, history and functions}

Interregionalism is a relatively new phenomenon, and it shows a wide range of different forms. An often-quoted definition says that interregionalism means institutionalized relations between world regions (Hänggi et al, 2006: 8). To put it differently, interregionalism 'refers to regular forms of cooperation between regions or actors from different regions and is a result of the parallel phenomena of globalization and regionalism' (Lehoczki, 2015). Both definitions emphasize that actors are needed from different regions, meaning that interregionalism connects continents, world regions and its different forms serve as useful forums to harmonize and deepen relations between entities that are geographically located far from each other. According to Hanggi, there are three groups or forms of inter-regional relations (Hänggi, 2000: 3-8).

Bi-regionalism or pure interregionalism or old interregionalism denotes group-to-group dialogues organized in a hub-and-spokes relationship mainly around the European Union (EU). There are usually no common institutions; both sides rely on their own organizational infrastructures. Examples are the dialogues of the EU with the Association of Southeast Asian Nations (ASEAN), the Mercosur, the South African Development Community (SADC) or the ASEAN-Mercosur dialogues.

Transregionalism means a dialogue process with a more diffuse membership, which does not necessarily only include regional organizations but also member states from more than two regions. Perhaps as a result of the greater heterogeneity and the autonomy members maintain from their regional organization, transregional forums tend to develop a modicum of organizational infrastructure such as a (virtual) secretariat or other (often informal) coordinating mechanisms. They are also called megaregions. Examples are the 
Asia-Europe Meeting (ASEM), the Asia-Pacific Economic Cooperation (APEC) and the Indian Ocean Rim Association for Regional Cooperation (IOR-ARC).

'Hybrid interregionalism' or 'quasi-interregional' relations include inter-continental forums (Africa-Europe process, Europe-Latin America relations, Far East-Latin America Cooperation or FEALAC) and strategic partnerships between a regional organisation and a state, such as those of the EU with the United States (US), Russia, China, Japan, India, Mexico or South Africa.

Recently, the term 'interregionalism without regions' within this category has emerged referring to cases as the IBSA (India, Brazil, South Africa) forum, or the BRICS (Brazil, Russia, India, China and South Africa), where regional hegemons claiming to speak for their regions interact with each other without the participation of their regional partners.

The history of interregionalism goes back to the origins of European integration after WWII, so interregionalism has been evolving parallelly with international regionalism (meaning regionalism at the 'above the state' level). The old version emerged from the 1960 s and basically meant the interregional dialogue of the European Economic Community (EEC) following a group to group scheme that started with the Yaoundé Convention (1963) - it was a convention between the EEC and the 18 African excolonies that had recently gained independence. In the next decades further interregional agreements followed initiated by the European integration and they were described as an attempt of the European Communities (EC) to strengthen their global actorness (Söderbaum et al., 2005: 373) and position and widen their trade opportunities through institutionalized relations with other parts of the world.

In the post bipolar period, interregionalism has gained greater recognition and has called for more focused academic attention. Instead of interpreted as simply a tool of EU external relations, now it is rather explained as a result of the altered international system (conceptualized through the framework of globalization) and the emergence and proliferation of new 'open' regional formations. Thus, the EU-centric hub-and-spokes architecture of the old interregionalism has progressively been replaced by one of multiple hubs, with an activating participation of old and new regional organizations, such as ASEAN, MERCOSUR or the Andean Community.

After the Millennium, a dynamic transformation of interregionalism started leading to the involvement of new types of actors and new - less institutionalized - patterns of interregional relations. Examples of 'hybrid interregionalism' and 'interregionalism without regions' (see above) emerged, where actors beyond the so-called Triad (such as Latin America, Asia and Africa) appeared as more and more active not only participants, but also initiators of interregionalism. As a result, examples of interregional institutions without involvement of developed countries emerged, changing the original focus of interregionalism. After 2000 the term 'non-triadic interregional forum' described these new forms of cooperation. The number of these forums is on the rise, strengthening the frameworks of South-South Cooperation (SCC) and resulting in a more active participation of the non-Western world in global governance. 
Before analysing Latin America's role in interregional relations, the functions of interregionalism should be detected to find out why states and regions join interregional forums and why Latin American actors perceive them as opportunities. Doidge (2011: 31-51) identifies and describes the following five functions of interregionalism.

Balancing basically means that group-to-group structures are created to avoid possible marginalization through maximizing autonomy and room for manoeuvre. Medium, smaller or weaker states typically seek to balance regional hegemons (the United States in case of Latin America) by institutional means. Through institutional coalitions they hope to impede, dilute and delay hegemonic policies, thereby increasing the latter's costs. Parallelly, an externally-oriented balancing is driven by constraining other actors or supporting their more active involvement in global multilateral forums, making them more stable and intense. It is thus hardly surprising that apart from the EU mainly entities as Singapore, Australia and Japan or newly emerging regional leaders such as South Africa, Brazil and India have taken the lead in proposing and establishing interregional forums.

Especially liberal institutionalists regard the phenomena of interregionalism as contributing to international institution-building. They give a new layer of interaction to the emerging global governance architecture linging actors that were separated before. Creating principles and norms they have a 'legalising effect on international relations', similarly to international institutions. Intra-regionally, interregional forums might become drivers of coordination as regional organizations seek to develop uniform positions and common grounds in interregional dialogues. Positive results are more efficient information flows, more intensive intra-regional interaction and strengthened regional cohesion, while preference for informality and lack of binding decisions constitute limitations.

Rationalizing refers to the fact that multilateral global forums have to work with a growing number of actors with diverse interests and increasingly complex policy issues. As a result, negotiations in global multilateral institutions are often exceedingly slow; World Trade Organization (WTO) rounds, for instance, take years to conclude. Negotiations between regional blocs might serve as a 'clearing house' function for global forums.

Agenda-setting is another suggested function of interregionalism. In the context of global governance, interregional forums may serve as platforms or arenas for great powers, regional organizations, coalitions of states, but also for smaller states to highlight and frame new global problems that need to be tackled by the international community and call attention for these issues.

Collective identity-building -as the fifth function - rests on the claim that interregional forums serve as facilitators of regional identity-building. Regional identities might be strengthened if interregional interaction point to differences between the regional self and regional other(s), generating and internalizing a repository of shared norms and beliefs and thus supporting regional awareness and cohesion. 
The functions introduced above mostly focus on the advantages and opportunities of interregionalism, explaining how interregional forums serve the interests and reinforce the role of smaller and medium states. Alfredo Robles gives a totally different perspective describing the phenomenon of interregionalism as a hegemonic project. Examining the example of Asia-Europe Meeting (ASEM) and following the ideas of dependency theory, he writes that inter-regional relations reflect post-colonial hierarchy. He is highly critical towards interregional forums claiming that it is asymmetrical and basically serves the interests of the Western countries (Robles, 2008).

\section{Latin America's involvement in interregionalism}

On behalf of Latin America, different types of actors participate in interregional relations. First of all, Latin American regional organizations are quite obvious actors. Latin American regionalism goes back to the 1960s, and it originally attempted to widen markets and counterbalance the relative marginalization of Latin America in the world economy after WWII. This first wave of Latin American regionalism was not successful and basically focused on trade relations between the member states.

The end of the Cold War and the introduction of market reforms and outwardlooking economic strategies in the 1990s brought new forms of regionalism in Latin America. Mercosur (Common Market of the South, Mercado Común del Sur) was established in 1991 with the participation of four South American countries (Brazil, Argentina, Uruguay and Paraguay) and it soon became the most ambitious and wellknown regional organization in Latin America, while the most promising one in the developing world. During the 1990s, EU-Mercosur relations gave an essential and highly publicized axe of strengthening interregional relations in the world, a typical case study of 'pure interregionalism'. The European Union had a strong ambition to build institutionalized relations with Mercosur supporting the development of the South American countries involved through trade liberalization and investments. The EU believed that in case of success it could serve as kind of a model for other regional organisations in the developing world. The 1990s brought dynamic progress in EUMercosur relations: substantial increase in trade flows, increasing European FDI targeting Latin America, ratification of EMIFCA (EU-Mercosur Interregional Framework for Cooperation Agreement) and finally, foundation of Mercosur-Europe Business Forum in 1999 (Faust, 2006: 160-166). Meanwhile, conflict emerged between different interest groups during free trade negotiations and neither Mercosur, nor the EU appeared to be coherent regarding trade liberalization. Negotiations between individual Latin American countries (such as Mexico and Chile) and the EU were concluded more successfully during these years - an agreement about free trade of goods between Mexico and the EU entered into force in 2000, about free trade of services in 2001, while the EU and Chile concluded an Association Agreement in 2002, which includes a comprehensive Free Trade Agreement, that entered into force in 2003. After 2000, EU-Mercosur 
relations slowed down, and finally stalled in 2004, mainly as a result of the fact that leading South American countries (first of all, Brazil) preferred global negotiations instead of interregional forums hoping that broader liberalization in agriculture could have better opportunities at the WTO level (Faust, 2006:165). Parallelly, Mercosur became the initiator of inter-regional links looking after new partners itself.

The European Economic Community (EEC) had bi-regional relations with the Andean Group and the Central American Common Market (CACM) already in the 1980s, the first agreements signed in 1983 and 1985, respectively. After 2000, these Latin American regional structures, plus CARICOM and the Caribbean Forum (CARIFORUM, which is a subgroup of the African, Caribbean and Pacific Group of States or ACP countries) gained importance again and negotiations with the EU got an impetus. Negotiations between the EU and the Andean Community resulted in a conflict of interests in trade issues, so currently group to group negotiations go on to strengthen political dialogue and cooperation, but "multi-party" trade negotiations were initiated with member states of the Andean Community. Central America soon emerged as the 'entity' negotiating with the EU instead of the CACM or the Central American Integration System, leading to an Association Agreement between the EU and Central America in 2012, while the Cariforum-EU Economic Partnership Agreement was signed in 2008 .

In the $21^{\text {st }}$ century, new regional actors emerged, first of all the Community of Latin American and Caribbean States (CELAC) established in 2010 with the involvement of all sovereign states of Latin America and the Caribbean; and the Pacific Alliance created in 2011 with Mexico, Peru, Colombia and Chile as members. These new structures brought new opportunities and maybe a new era for Latin America's involvement in interregionalism. CELAC is the very first example of a regionwide institution gathering 33 Latin American and Caribbean states, which was intended to reinforce Latin America's status and bargaining power in the world. The history of EU-Latin America Summits go back to 1999, and it was replaced by EU-CELAC Summits in 2010, when participants in Madrid agreed to create an EU-CELAC Action Plan. Although this bi-regional cooperation evolved in the following years (the second summit was convened in 2015 in Brussels), concrete results are still lacking, which was an essential criticism already towards the EU-Latin America Summits. On the other hand, CELAC seems to be active in building inter-regional cooperation: in 2014 China-Latin America and the Caribbean Summit was held in Brasilia, then in 2015 the first Ministerial Meeting of China-CELAC Forum was held in Beijing, marking the launch of the Forum. Besides, CELAC plans to set up offices in various countries, such as Canada, the United States, Turkey, South Korea, Saudi Arabia, the Russian Federation, etc. (CELAC, 2019). The birth of the Pacific Alliance shows an opening towards the Pacific region from Latin America (a bridge to Asia), therefore PA might be an important tool of bi-regional institution building. Till now, not surprisingly, relations between PA and the EU are the most 
structured, but building closer links with China and other Asian partners is probable in the future, while the United States could end up as a member state.

Subregions, such as South America, Central America and after all, Latin America are also 'actors' participating typically in interregional summits, which are rather loose, informal ways of interregional cooperation. EU-Central America negotiations and EULatin America Summits have been mentioned, but the Forum for East Asia-Latin America Cooperation (FEALAC) has to be added as a relatively new form of hybrid interregionalism. FEALAC was established in 1999, has 36 member states and is one of the first cases of non-Triadic interregionalism, consisting of regular meetings held at three levels: the Foreign Ministers, the Senior Officials and the Working-level Officials.

South America has become a rather active participant in inter-regionalism in the last two decades. Brazilian president Luiz Inácio 'Lula' da Silva (2003-2011) was a central figure in building a new axis of South-South Cooperation with the involvement of South America as a region acting on its own; Summits of South American-Arab Countries (last summit organized in 2015), Africa-South America Summits (last one convened in 2013) are the clearest examples, although these frameworks seem to be losing ground since Brazil has had to focus on domestic political and economic challenges.

At the state level, basically the biggest Latin American economies, Mexico, Chile and Brazil have the most intense inter-regional relations. Mexico is geographically close (neighbouring) to the US, and as a result of the North American Free Trade Agreement (NAFTA) signed in 1994, Mexican economy is highly dependent on the United States. For Mexico, diversification is an essential objective driving negotiations with the EU and being a founding member of CELAC and PA. Chile is an extremely open economy compared to other Latin American countries, so Chile's involvement is based on primarily economic (trade) relations, plus Chile is not a member of Mercosur, neither of the Andean Community, so it has to build its own inter-regional relations. Brazil has had a central role in Latin America's and especially South America's involvement in interregionalism in the last years starting with the Lula administration's declaration of the foreign policy principle "autonomy through diversification" which had the direct aim to explore and develop new links in the world. Besides, Brazil is a member of G20 (other Latin American members are Mexico and Argentina), BRICS (a typical case of interregionalism without regions (see above) and IBSA (India, Brazil, South Africa) Forum. Brazil is also a member of G4 -with India, Japan and Germany-, which is a group of countries from different regions aiming to reach permanent membership in the United Nations Security Council.

The history of Latin America's experiences with inter-regionalism can be divided into three phases. The first - rarely mentioned- phase was the Inter-American period starting with the creation of the Pan-American Union (1910) and later the Organization of American States (OAS, 1948) - both basically serving US interests. These interregional frameworks were highly asymmetrical, initiated and dominated by the US. During the Cold War, the most important US objective in Latin America was to contain communism, 
therefore OAS took it as a priority - Latin American interests could not really influence the agenda. Then a second phase started in the 1980s, when the establishment of the Rio Group brought the opportunity to build interregional relations with Europe (dialogue was established in 1990), in parallel with the Mediterranean enlargement of the European integration (1986). In this second phase, Europe 'reinvented' Latin America and served as a promising alternative or counterbalance to US influence in the region. During the 1990s the EU was an important trade partner and investor for the Latin American region, which of course contributed to stronger and more institutionalized relations between the EU and Latin America.

The millennium brought a dynamic third phase of interregionalism in Latin America: the political turn in Latin America called 'pink tide' -an expression used by Western authors and the international media- led to diversification of foreign relations of South American countries, while traditional ties with the US and Europe cooled down. Brazil's role was central in this period, as the Lula administration attempted to act as a regional leader and become the "face" of South America. Besides, Lula's idea was to strengthen links with other emerging powers and developing regions in order to gain presence and influence in the global arena. Novelty of the third phase was that Latin America -for the first time- initiated interregional forums itself with a new range of actors, such as China, India, the Middle East or Africa, and had a relatively active role in inter-regional links compared to previous decades. In new, non-traditional forms of interregionalism, such as FEALAC, Summit of South American-Arab Countries or the IBSA Forum, Latin American actors are given the chance to influence the agenda, discuss topics important for them and participate as initiators and partners instead of followers. The strongest inter-regional ties were built with China and Asia in general during this third phase reflecting changing patterns of Latin American trade relations and sources of investments. The birth of CELAC is an important opportunity from the perspective of future inter-regional relations as it comprises all the countries from the region supporting Latin America's role as a single pole in the world - in spite of the fact that CELAC as an actor is far from being unified or coherent.

If the -above described- functions of interregionalism are concerned, the three phases could be characterized by different sets of functions. During the Inter-American period, Latin American countries did not have conscious motivations or objectives with the participation. Institution-building was a very strong function in these decades, as the Inter-American regional structure meant the very first multifunctional regional institutions in the world; the establishment of "thematic" institutions was really an early pioneer act in the history of (inter-)regional cooperation: the Pan American Health Organization (1902), which later also became the regional office of the future World Health Organization; the Inter-American Juridical Committee (1906); the Inter-American Children's Institute (1927); the Inter-American Commission of Women (1928); the Pan American Institute of Geography and History (1928); the Inter-American Indian Institute (1940); the Inter-American Institute for Cooperation on Agriculture (1942) (OAS, 2019). 
Washington was the obvious leader of Pan-American institutions, but Latin American countries were given the chance to influence the agenda and raise topics important for them. Most Latin American countries were founding members of the League of Nations, so between the two World Wars Latin Americans had the chance for "socializing" in various multilateral forums. The function of identity building was dual in this period: the idea of Pan-Americanism reinforced the 'American identity' of Latin Americans, their belonging to the Western Hemisphere, while the obvious differences in weight, bargaining power and development highlighted the asymmetries in the Americas, reinforcing 'Latin American' identity and its distinction from Anglo-Saxon America.

During the second phase, institution building was again an essential function as EULatin America relations brought typical and often referred to examples of pure interregionalism in the 1990s with a strong group to group approach. Balancing emerged as a new function, especially EU-Mercosur relations are described as an outcome of Latin American (and also European!) concerns over Washington's desire for a hemispherewide free trade zone, the Free Trade Area of the Americas (FTAA), which would strengthen US hegemony in the Southern hemisphere. The EU-Central American dialogue follows a similar logic, but EU-Mexico relations also target balancing the influence of the close hegemon.

The third phase of Latin America's involvement in interregionalism and the various non-triadic interregional forums were launched to balance American (US) and European dominance in the United Nations (UN) and the global economic and financial institutions. Diversification of foreign relations, stronger integration in world economy and more intense involvement in multilateral forums were essential motivations in this period. Non-triadic interregional cooperation has the clear function of agenda setting for Latin Americans, as power structures among the participants are less asymmetrical in these cases. Latin American priorities, such as a multipolar world order, social and environmental issues, fight against illegal drug trade and organised crime are put on the table and discussed on these forums. Finally, identity building has become a function stronger than ever, as Latin America and/or South America acts as an autonomous actor after the Millennium. Besides, identity formation has a novel element reinforced in the last decades - belonging to and being an active member of the Global South.

\section{Conclusion: Latin American characteristics of interregionalism}

Compared to other regions of the developing world, Latin America has quite old, intense and widespread involvement in interregional relations. Outside the Triad, Latin America is an experienced, determining and active actor in inter-regional cooperation. The region participates in a wide range of inter-regional forums, alliances, cooperation and institutions at different levels, which are states, regional organizations and regions, such as South America, Central America and Latin America. This embeddedness in inter-regional 
structures is an essential advantage for the region, as presence and participation in these forums offer the opportunity to articulate interests and find tools to enforce them.

On the contrary, there are obvious limitations to Latin America's participation in inter-regional relations. First of all, Latin America is seemingly not able to act as a unified entity despite the creation of CELAC in 2010. Although, it represents Latin America and could be an effective tool to give Latin America a stronger position in inter-regional forums, members, of course, do not equally participate. Brazil and Mexico were the most influential members at the birth of CELAC, while today both countries seem to lose interest in the organization. Brazil is still the strongest and most influential Latin American participant in inter-regional forums, while a strategic alliance was formed between the EU and Brazil in 2007 motivated by the fact that during these years Brazil seemed to enter the international arena as a global player. But political and economic crisis in Brazil and the presidency of Jair Bolsonaro probably seriously hinder the continuation of the strong motive to build an inter-regional architecture with a central Brazilian role. In general, the lack of continuity in foreign policy making in Latin America presents an obvious limitation to conscious, well-designed and defined participation in inter-regional cooperation. Still, inter-regional institutions and the century-long experience with them is a rich source of soft power for Latin America, the inter-regional architecture is built, while the contents and concrete results shall come.

\section{Works Cited}

CELAC (2019). Official homepage. Available at: http://celacinternational.org/, access date: $20-10-2019$.

Faust, Jörg (2006). The European Union's relations with MERCOSUR: the issue of interregional trade liberalization. In: Hänggi, H. - Roloff, R. - Rüland, J. (eds.). Interregionalism and international relations. London: Routledge. 155-168.

Doidge, Mathew (2011). The European Union and Interregionalism: Patterns of Engagement. London: Ashgate.

Hänggi, Heiner (2000). Inter-regionalism: empirical and theoretical perspectives. Paper presented for the workshop "Dollars, Democracy and Trade: External Influence on Economic Integration in the Americas", Los Angeles. Available at: http://www.cap.lmu.de /transatlantic/download/Haenggi.PDF, access date: 27-09-2010.

Hänggi, Heiner - Roloff, Ralf - Rüland, Jürgen (2006). Inter-regionalism: A new phenomenon in international relations. In: Hänggi, H. - Roloff, R. - Rüland, J. (eds.). 2006. Inter-regionalism and international relations. London: Routledge. 3-15.

Lehoczki, Bernadett (2015). Relations between China and Latin America: Interregionalism beyond the Triad. Society and Economy, 37 (3). 379-402. 
Interregionalism: the Case of Latin America

OAS (2019). Official Homepage. Available at: http://www.oas.org/en/about/ our_history.asp, access date: 20-10-2019.

Robles, Alfredo C. (2008). The Asia-Europe Meeting: The theory and Practice of Interregionalism. London: Routledge.

Söderbaum, Fredrik - Stalgren, Patrik - Van Langenhove, Luk (2005). The EU as a Global Actor and the Dynamics of Interregionalism: a Comparative Analysis. Journal of European Integration, 27(3). 365-380. 